\title{
Penyuluhan Tentang Menyikapi Wabah Covid-19 Melalui Hidup Bersih dan Sehat Dengan Cara Mengolah Limbah Rumah Tangga di Kelompok PKK RT01 RW13 Padasuka Indah, Kelurahan Padasuka, Kota Cimahi
}

\section{Counseling on Responding to the Covid-19 Outbreak through Clean and Healthy Living by Treating Household Waste in the PKK RT01 RW13 Padasuka Indah Group, Padasuka Village, Cimahi City}

\author{
Yuli Astuti Hidayati ${ }^{1, a}$, Eulis Tanti Marlina ${ }^{1}$, Wowon Juanda ${ }^{1}$, Deden Zamzam Badruzaman ${ }^{1}$, \\ Ellin Harlia ${ }^{1}$ \\ ${ }^{1}$ Fakultas Peternakan, Universitas Padjadjaran, Jatinangor - Sumedang \\ aemail: yuli.astuti@unpad.ac.id
}

\begin{abstract}
Abstrak
Pandemi Covid-19 menyebar dengan cepat dari satu wilayah ke wilayah lainnya. Penyebarannya sangat cepat, sehingga hampir seluruh negara yang terjangkit wabah Covid-19, tidak ada yang mempersiapkan masyarakatnya untuk menghadapi hal tersebut. Kebijakan pemerintah mengharuskan masyarakat untuk stay at home, bahkan bekerja, sekolah dilakukan dari rumah, menggunakan metode daring. Sosialisasi dan penyuluhan tentang pemahaman Covid-19 serta hidup bersih dan sehat dengan mengolah limbah rumah tangga menjadi pupuk organik, perlu dilakukan agar masyarakat dapat bersikap positif dalam menghadapi pandemi Covid-19 ini. Sebelum dilakukan sosialisasi dan penyuluhan tentang Covid-19, masyarakat secara umum telah mengetahui mikroorganisme penyebab penyakit, cara pencegahannya dengan melakukan pola hidup bersih dan sehat tetapi secara khusus untuk kasus Covid-19, masyarakat masih belum sepenuhnya mengetahui, dan masyarakat belum melakukan pengolahan limbah dapur sebagai wujud pola hidup bersih dan sehat, hal ini tergambar dalam hasil pre-test dan post-test yang dilakukan pada ibu-ibu PKK. Hasil kegiatan penyuluhan menunjukkan bahwa terjadi peningkatan pengetahuan tentang penyebab penyakit, gejala Covid19 dan dilakukannya tindakan preventif dengan dilaksanakannya hidup bersih dan sehat oleh ibu-ibu, serta dilakukannya pengolahan limbah dapur dan pemanfaatan kompos sebagai pupuk organik untuk tanaman di sekitar rumah.
\end{abstract}

Kata Kunci: Covid-19, sikap positif, hidup bersih, pengelolaan limbah, pengomposan.

\begin{abstract}
The Covid-19 pandemic is spreading rapidly from one region to another. The spread is so fast, that in almost all countries affected by the Covid-19 outbreak, nothing has prepared its people to face it. Government policy requires people to stay at home, even work, go to school from home, using online methods. Socialization and counseling about the understanding of Covid-19, live clean and healthy life by processing household waste into organic fertilizer needs to be done so that people can be positive in facing this Covid-19 pandemic. Prior to socialization and counseling about Covid-19, the public in general had known the microorganisms that caused the disease, how to prevent them by adopting a clean and healthy lifestyle but specifically for the case of Covid-19, the public still did not fully know, and the community has not treated kitchen waste as a form of a clean and healthy lifestyle, this is reflected in the pre-test and post-test results. test conducted on PKK members. The conclusion of the socialization and counseling carried out at RT01 RW20 Padasuka Village, Cimahi Tengah District, Cimahi City as a whole can increase the knowledge of PKK members in terms of causes of disease, symptoms of Covid-19, preventive action by carrying out a clean and healthy life and as well as processing kitchen waste and utilizing the resulting compost.
\end{abstract}

Key words: Covid-19, positive attitude, clean life, waste management, composting. 


\section{Pendahuluan}

Pada akhir tahun 2019, dunia dikejutkan dengan suatu penyakit pneumonia yang tidak seperti biasanya, awal munculnya di kota Wuhan, propinsi Hubei negara China. Penyebarannya sangat cepat, awal tahun 2020 penyakit ini telah menyebar di berbagai provinsi lain di China, menyebar juga ke negara Thailand, Jepang, dan Korea Selatan, dan hampir 190 negara terserang penyakit ini, sehingga menjadi pandemi. WHO mengumumkan nama penyakit ini yaitu Coronavirus Disease (Covid-19) yang disebabkan oleh virus Severe Acute Respiratory Syndrome Coronavirus-2 (SARS-CoV-2). Penyakit ini dilaporkan masuk ke Indonesia awal Maret 2020, sejumlah dua kasus di kota Bogor, kemudian dengan cepatnya menyebar ke wilayah lain seperti Jakarta, Bandung, dan wilayah lain di pulau Jawa dan luar Jawa. Pada 16 Maret 2020, pemerintah mengumumkan agar masyarakat stay at home untuk mencegah penularan penyakit ini. Aktivitas belajar dan bekerja semua dilakukan dari rumah (work from home) dalam keadaan daring.

Berdasarkan hal tersebut perlu dilakukan penyuluhan tentang pemahaman Covid-19 serta hidup bersih dan sehat, salah satunya dengan cara mengolah limbah rumah tangga agar masyarakat dapat bersikap positif dalam menghadapi pandemi Covid-19 ini. Lokasi penyuluhan dipilih Wilayah Padasuka, RT01 RW13, Kelurahan Padasuka, Kecamatan Cimahi Tengah, Kota Cimahi yang merupakan daerah perumahan dengan penduduk yang tingkat pendidikannya memadai dan sebagai kader PKK, sehingga diharapkan setelah mengikuti penyuluhan, masing-masing dapat menyampaikan pengetahuan dan ketrampilan yang diperoleh kepada masyarakat di sekitarnya. Kader PKK ini tergabung dalam grup Whatsapp (WA), sehingga mempermudah untuk koordinasi pelaksanaan penyuluhan yang dilakukan secara daring, menggunakan aplikasi Google Form dan materi penyuluhan disampaikan menggunakan slide show yang dikirim melalui grup WA.

Dalam menghadapi pandemi Covid-19 ini perlu disampaikan kepada masyarakat pengertian dasar tentang Covid-19, yaitu merupakan singkatan dari Coronavirus Disease 19 yang berarti suatu penyakit yang disebabkan oleh virus corona dan mewabah di akhir tahun 2019. Apa itu virus? Penjelasan virus dimulai dengan penjelasan tentang mikroorganisme. Tortora et al, (2016) menyatakan bahwa mikroorganisme merupakan organisme/makhluk hidup yang berukuran sangat kecil, sehingga untuk melihatnya diperlukan bantuan alat yang disebut mikroskop. Mikroorganisme ada yang bersel satu/uniseluler, yaitu bakteri, ragi; ada yang bersel banyak/ multiseluler, yaitu jamur, ada juga yang tidak mempunyai sel, yaitu virus. Beberapa contoh spesies dari bakteri adalah Escherichia coli, Clostridium tetani, Salmonella typosa, spesies jamur adalah Rhizophus oligosporus, Neurospora sp, species ragi adalah Saccharomyces cereviceae, spesies virus adalah virus hepatitis, virus polio, virus corona.

Covid-19 merupakan virus dengan ukuran sekitar 120 nanometer $(0,12 \mu \mathrm{m})$, bentuknya menyerupai mahkota, sehingga disebut Corona. Tanda-tanda terinfeksi Covid-19 dan masa inkubasi, seperti yang dilansir oleh Immamatul Silfia pada KOMPAS.com, adalah demam tinggi $>38^{\circ} \mathrm{C}$, batuk kering pada hari ke 1, lanjut lemas, nyeri otot, sakit tenggorokan dan sesak napas pada hari hari ke-5, lanjut sakit kepala. Pada hari ke 7 diharuskan masuk rumah sakit, hari ke-8 terjadi sindrom gangguan pernafasan akut, kemudian hari ke 10 masuk Intensive Care Unit (ICU) dan pada hari ke-17 sembuh.

Menurut Yuliana (2020), Adityo Susilo (2020), dan Walsyukurniat Zendrato (2020), ketika penyebaran Covid-19, virus corona bersifat zoonotic, awalnya berkembang pada tubuh hewan sebelum akhirnya menyerang manusia, ketika sudah menginfeksi manusia, penyebaran melalui droplet pernafasan, percikan batuk/ bersin 
akan menempel di permukaan benda/kulit manusia, virus akan berpindah ketika manusia menyentuh benda/melakukan kontak fisik dengan manusia lain, kemudian virus akan menginfeksi manusia ketika tangan menyentuh wajah, mulut, hidung, dan mata, untuk itu perlu dilakukan sosialisasi kepada masyarakat tentang bagaimana mencegah penularan infeksi Covid-19, yaitu dengan cara mencuci tangan dengan sabun dan air mengalir selama 20 detik, atau menggunakan hand sanitizer, menghindari menyentuh area wajah (mata, hidung, mulut) sebelum membersihkan tangan, jangan keluar rumah jika kurang sehat dan memiliki gejala flu, menghindari kontak fisik dengan orang lain $(1 \mathrm{~m})$, gunakan masker untuk menutup mulut dan hidung, membersihkan barang-barang yang sering digunakan (seperti ponsel, laptop, dan meja) dengan desinfektan, menerapkan gaya hidup bersih dan sehat (pola makan, olahraga, dan menghindari begadang untuk menjaga kekebalan tubuh. Penggunaan desinfektan sejalan dengan pendapat Larasati dan Haribowo (2020) yang menyatakan penggunaan antiseptik dan desinfektan untuk mencegah penularan Covid-19 efektif bila pemilihannya tepat serta digunakan sesuai dengan peruntukannya.

Gaya hidup bersih di antaranya dengan mengolah limbah rumah tangga menjadi pupuk organik. Limbah rumah tangga merupakan limbah dari kegiatan dalam rumah tangga, yang paling banyak dihasilkan adalah limbah dapur berupa sampah organik. Limbah dapur dapat diolah dengan menggunakan teknologi pengomposan dan menghasilkan kompos yang dapat dimanfaatkan sebagai pupuk organik. Pengomposan merupakan proses degradasi bahan organik secara aerob, yang melibatkan mikroorganisme. Pada proses pengomposan sampah dapur melibatkan mikroorganisme indigenos. Pada penyuluhan ini disampaikan kepada masyarakat langkahlangkah mengolah sampah dapur dengan proses pengomposan, yaitu mengumpulkan sampah dapur dalam suatu wadah (karung), yang sebelumnya sampah dipotong-potong untuk memperluas permukaan sampah, kemudian setelah terkumpul, sampah dapur diinkubasi selama dua bulan dan setiap seminggu sekali dilakukan pembalikan dengan maksud memberikan aerasi pada tumbukan sampah dapur tersebut. Setiap hari dilakukan pencatatan suhu pada tumpukan sampah, dimaksudkan untuk memastikan bahwa peningkatan suhu yang terjadi menandakan proses degradasi bahan organik sampah sedang berlangsung. Apabila suhu mulai menurun dan berakhir sama dengan suhu lingkungan, hal tersebut menandakan bahwa proses pengomposan sudah berakhir dan menghasilkan kompos yang siap diaplikasikan pada tanaman di sekitar rumah. Sampah dipotong-potong dengan maksud memperluas permukaan untuk kontak dengan mikroorganisme, perlakuan pembalikan untuk memberikan aerasi, pengukuran suhu untuk mengetahui proses pengomposan sedang berlangsung, hal ini merupakan persyaratan dari proses pengomposan. Hal ini sejalan dengan pendapat Suwatanti dan Widiyaningrum (2017) yang menyatakan fluktuasi harian faktor lingkungan (suhu, $\mathrm{pH}$, kelembaban) selama pengomposan berpengaruh terhadap kualitas kompos. Ayumi dkk (2017) menyatakan pengomposan dengan tumpukan statis beraerasi dan pengomposan dengan rak segitiga memberikan hasil terbaik. Menurut Utomo dan Nurdiana (2018) bahwa perlu diperhatikan ukuran bahan yang akan digunakan, karena ukuran bahan sangat mempengaruhi proses pengomposan.

Tujuan kegiatan ini adalah memberikan penyuluhan secara daring melalui metode ceramah mengenai Covid-19 dan hidup bersih, dan melalui pemberian keterampilan pengolahan limbah rumah tangga menjadi pupuk organik. Kegiatan ini dimaksudkan agar masyarakat sasaran dapat bersikap positif dalam menghadapi Covid-19 ini.

\section{Materi dan Metode Pelaksanaan}

Metode pendekatan untuk menyelesaikan masalah 
Dalam rangka meningkatkan pengetahuan tentang pemahaman Covid-19, dilakukan penjelasan materi tentang penyebab Covid-19, tanda-tanda infeksi Covid-19, penyebaran Covid-19, pencegahan penularan Covid-19, langkah-langkah mengolah sampah dapur dengan proses pengomposan. Untuk mengukur perubahan pengetahuan dan pemahaman tentang Covid19 maka dilakukan pre-test dan post-test.

\section{Metode yang dilaksanakan untuk meneyelesaikan masalah.}

Penyampaian materi penyuluhan dilaksanakan dengan metode daring, menggunakan aplikasi Whatsapp (WA) untuk koordinasi dengan ibu-ibu PKK, kemudian dilakukan pre-test untuk mengetahui pemahaman tentang Covid-19, menggunakan Google Form dan tautannya disampaikan pada grup WA. Selanjutnya materi penyuluhan disampaikan dengan slideshow dan disampaikan melalui WA group. Selanjutnya untuk mengetahui efektivitas penyuluhan, dilakukan post-test, apakah pengetahuan dan pemahaman tetang Covid19 dari ibu-ibu PKK tersebut meningkat.

\section{Prosedur kerja dalam menyelesaikan masalah.}

1. Buka tautan yang tersedia

2. Isi data diri

3. Baca dan jawab pertanyaan dengan cara memilih YA atau TIDAK

4. Buka tautan yang tersedia lalu dengarkan materi penyuluhan yang telah disediakan

5. Baca dan jawab pertanyaan selanjutnya dengan cara memilih YA atau TIDAK

6. Submit.

Kegiatan penyuluhan secara daring dilaksanakan pada tanggal 8 Mei 2020 dengan kelompok sasarannya adalah ibu-ibu PKK Komplek Padasuka Indah RT01 RW13 Kelurahan Padasuka, Kecamatan Cimahi Tengah, Kota Cimahi

\section{Hasil dan Pembahasan}

Kegiatan pengabdian kepada masyarakat diikuti oleh ibu-ibu PKK RT01 RW13 Kelurahan Padasuka Cimahi, berjumlah 26 orang. Ibu-ibu mendapatkan penjelasan tentang pengetahuan dasar mikroorganisme, terutama penyebab Covid19 , penularan serta pencegahannya. Selain itu juga mendapat penjelasan tentang pola hidup bersih dan sehat, sesuai yang dianjurkan oleh pemerintah. Dalam kegiatan PKM kali ini mengajak masyarakat untuk hidup bersih pada tubuh maupun lingkungan dan sehat dengan mengonsumsi makanan seimbang dan berolahraga. Hal ini dimaksudkan untuk meningkatkan imun dalam tubuh, sehingga terhindar dari Covid-19. Kegiatan ini sejalan dengan Rizka Ausrianti, dkk (2020) yang menyatakan bahwa perlu dilakukan kegiatan untuk meningkatkan kemampuan untuk pencegahan terjangkitnya covid 19, meningkatkan kemampuan agar tidak menularkan kepada keluarga atau konsumen atau pengguna dari ojek daring. Demikian juga sejalan dengan Zahrotunnimah.(2020) yang menyatakan perlunya memberikan edukasi dan komunikasi kepada masyarakat dalam menghadapi bencana global dan pencegahannya.

Salah satu hidup bersih dan sehat dalam rumah tangga, diwujudkan dengan cara mengolah limbah dapur dengan metode pengomposan. Kegiatan ini menghasilkan produk yang disebut kompos, yang dapat dimanfaatkan untuk memupuk tanaman di sekitar rumah. Hal ini sejalan dengan pendapat B Bachtiar. dan A. H. Ahmad. 2019. Pupuk kompos bermanfaat dalam meningkatkan produktivitas media tanam tanaman dengan meningkatkan sifat fisik, kimia, dan biologis tanah; penggunaannya aman dan tidak merusak lingkungan; dan tidak memerlukan banyak biaya dan proses pembuatannya mudah.

Pengetahuan yang diperoleh diharapkan dapat diterapkan dan disebarluaskan pada anggota masyarakat di Kelurahan Padasuka pada khususnya dan daerah sekitarnya pada 
umumnya. Ibu-ibu PKK merupakan kader yang potensial untuk menyebarkan inovasi dan peningkatan pengetahuan pada masyarakat. Untuk itu perlu dilakukan kerja sama yang berkelanjutan dengan kader PKK untuk menyampaikan program-program pengabdian kepada masyarakat yang sifatnya meningkatkan pengetahuan yang menunjang pembangunan. Hasil analisis data keberhasilan kegiatan penyuluhan disampaikan pada Tabel 1 .

Tabel 1. Hasil Analisis Kuesioner Pre-test dan Post-test.

\begin{tabular}{|c|c|c|c|}
\hline No & Pengetahuan & $\begin{array}{c}\text { Sebelum } \\
\text { Penyuluhan } \\
\text { (\% yang } \\
\text { mengetahui) }\end{array}$ & $\begin{array}{c}\text { Sesudah } \\
\text { Penyuluhan } \\
\text { (\% yang } \\
\text { mengetahui) }\end{array}$ \\
\hline 1 & Apakah ibu-ibu mengetahui tentang mikroorganisme? & 38,46 & 100 \\
\hline 2 & Apakah ibu-ibu mengetahui tentang bakteri? & 84,61 & 100 \\
\hline 3 & Apakah ibu ibu mengetahui tentang virus? & 84,61 & 100 \\
\hline 4 & $\begin{array}{l}\text { Apakah ibu-ibu mengetahui tentang bahayanya wabah } \\
\text { Covid-19? }\end{array}$ & 100 & 100 \\
\hline 5 & $\begin{array}{l}\text { Di lingkungan ibu-ibu apakah pernah dilakukan } \\
\text { penyuluhan/sosialisasi tentang wabah Covid-19? }\end{array}$ & 0 & 100 \\
\hline 6 & $\begin{array}{l}\text { Apakah ibu-ibu mengetahui tentang wabah Covid-19 } \\
\text { dari sosmed, TV, Koran? }\end{array}$ & 100 & 100 \\
\hline 7 & $\begin{array}{l}\text { Apakah ibu-ibu selalu tinggal dirumah (stay at home) } \\
\text { setiap hari? }\end{array}$ & 76,92 & 100 \\
\hline 8 & Apakah ibu-ibu mengetahui tentang desinfektan? & 46,15 & 100 \\
\hline 9 & $\begin{array}{l}\text { Apakah ibu-ibu selalu membersihkan jendela dan } \\
\text { pintu rumah dengan menggunakan desinfektan? }\end{array}$ & 57,69 & 100 \\
\hline 10 & Apakah ibu-ibu selalu mandi $2 x$ sehari? & 84,61 & 100 \\
\hline 11 & $\begin{array}{l}\text { Apakah ibu-ibu selalu mencuci tangan setiap hari lebih } \\
\text { dari 5x? }\end{array}$ & 38,46 & 100 \\
\hline 12 & $\begin{array}{l}\text { Apakah ibu-ibu selalu membersihkan perabot rumah } \\
\text { tangga (meja kursi, lemari, rak hiasan) seminggu } \\
\text { sekali? }\end{array}$ & 100 & 100 \\
\hline 13 & $\begin{array}{l}\text { Apakah setiap hari ibu-ibu selalu mengonsumsi buah- } \\
\text { buahan dan sayur-sayuran? }\end{array}$ & 100 & 100 \\
\hline 14 & $\begin{array}{l}\text { Apakah setiap hari ibu-ibu mengonsumsi } \\
\text { susu/telur/daging ayam/daging sapi/ikan? }\end{array}$ & 100 & 100 \\
\hline 15 & $\begin{array}{l}\text { Apakah ibu-ibu mengonsumsi vitamin } \mathrm{C} \text { dan E setiap } \\
\text { hari? }\end{array}$ & 19,23 & 100 \\
\hline 16 & Apakah ibu-ibu selalu berjemur di pagi hari & 38,46 & 100 \\
\hline 17 & $\begin{array}{l}\text { Apakah ibu-ibu mengetahui kalau limbah dapur dapat } \\
\text { diolah menjadi pupuk organik? }\end{array}$ & 53,85 & 100 \\
\hline 18 & Apakah ibu-ibu mengetahui proses pengomposan? & 0 & 100 \\
\hline 19 & $\begin{array}{l}\text { Apakah ibu-ibu mengolah limbah dapur dengan proses } \\
\text { pengomposan? }\end{array}$ & 0 & 100 \\
\hline 20 & $\begin{array}{l}\text { Apakah ibu-ibu memupuk tanaman di sekitar rumah } \\
\text { dengan menggunakan kompos? }\end{array}$ & 84,62 & 100 \\
\hline
\end{tabular}


Berdasarkan hasil analisis pada Tabel 1, menunjukkan bahwa ibu-ibu PKK RT01 RW13 Kelurahan Padasuka, secara keseluruhan $(100 \%)$ dari awal, mereka mengetahui ciri-ciri gejala Covid-19 dari sosial media WA, TV, dan sebagian besar mereka juga mengetahui tentang bakteri dan virus penyebab penyakit $(84,61 \%)$, namun tentang mikroorganisme secara umum, mereka belum mengetahui $(38,46 \%)$. Pengetahuan tentang menjaga kebersihan lingkungan, dari awal mereka semua (100\%) sudah menjaga lingkungan agar selalu bersih dengan cara membersihkan perabot rumah tangga, namun secara spesifik dan berkaitan dengan Covid-19 di antaranya bahwa mereka harus sering mencuci tangan, membersihkan perabot dengan menggunakan desinfektan, pengetahuan dengan hal tersebut hanya dicapai 38,46-57,69\%. Kemudian berkaitan dengan tindakan pencegahan tertular Covid19 yaitu dengan menjaga kesehatan tubuh, mereka $(100 \%)$ telah menerapkan konsumsi makanan seimbang yaitu dengan mengonsumsi sumber protein hewani dan sayur-sayuran serta buah-buahan. Namun secara spesifik mengonsumsi vitamin $\mathrm{C}$ dan vitamin $\mathrm{E}$, hanya 19,23\% dari mereka yang telah mengonsumsi. Hidup bersih dan sehat yang salah satunya diwujudkan dengan mengolah limbah dapur menjadi pupuk organik, hanya sebagian dari mereka yang mengetahui $(53,85 \%)$, mereka belum mengetahui apa yang dimaksud dengan proses pengomposan, namun sebagian besar dari mereka $(84,62 \%)$ sudah memanfaatkan kompos untuk memupuk tanaman di sekitar rumah, dengan cara membeli pada penjual tanaman.

Materi penyuluhan disampaikan dengan bahasa yang sederhana dan mudah dimengerti, sehingga setelah proses penyuluhan sangat nyata hasil yang diperoleh, yaitu meningkatkan pengetahuan yang berkaitan dengan penyebab penyakit, gejala Covid-19, tindakan preventif dengan melaksanakan hidup bersih dan sehat, pengetahuan mengolah sampah dapur dengan proses pengomposan, memanfaatkan kompos.
Hal ini tergambar pada hasil post test yang menunjukkan bahwa 100\% ibu-ibu PKK mengetahui dan memahami hal-hal yang berkaitan dengan penyebab Covid-19, tandatanda infeksi Covid-19, penyebaran Covid19, pencegahan penularan Covid-19, serta melakukan pengolahan limbah dapur dan memanfaatkan kompos yang dihasilkan.

Materi penyuluhan yang disampaikan sejalan dengan pendapat H Tandra (2020), menyatakan bahwa hidup sehat melindungi diri dan orang lain, dengan menjaga tiga hal yaitu Jati (jaga hati) dengan cara berpikir positif, jangan panik, jangan takut, jangan kuatir kemudian Jari (jaga diri) meliputi perilaku hidup sehat, jaga jarak, pakai masker, cuci tangan, olah raga 30 menit per hari, berjemur selama 15 menit, tidur 7-8 jam, jam makan teratur, badan yang sehat didapat dari gaya hidup yang benar, lalu Jamu (jaga mulut) setiap asupan makanan yang sehat akan menaikkan daya tahan hidup, jangan memakan makanan mengandung lemak tinggi, jangan memakan makanan yang mengandung gula, dianjurkan memakan ikan, telur, susu, daging ayam, buah-buahan, sayursayuran. Sejalan juga dengan pendapat Gesriantuti N dkk. (2016) yang menyatakan perlu upaya pemanfaatan limbah organik rumah tangga secara tepat agar tidak menimbulkan masalah bagi lingkungan sekitarnya.

\section{Kesimpulan}

Kegiatan penyuluhan yang dilakukan di RT01 RW20 Kelurahan Padasuka Kecamatan Cimahi Tengah Kota Cimahi secara keseluruhan dapat meningkatkan pengetahuan dan ibu-ibu PKK dalam hal penyebab penyakit, gejala Covid-19, tindakan preventif dengan melaksanakan hidup bersih dan sehat serta melakukan pengolahan limbah dapur dan memanfaatkan kompos yang dihasilkan.

\section{Daftar Pustaka}

Susilo A., Rumende, CM, Pitoyo CW, Santoso WD, Yulianti M, 
Herikurniawan, Sinto R, Singh G, Nainggolan L, Nelwan EJ, Chen LK, Alvina, Widhani, Wijaya E, Wicaksana B, Maksum M, Annisa F, Jasirwan COM, Yunihastuti E. 2020. Coronavirus Disease 2019: Tinjauan Literatur Terkini. Jurnal Penyakit Dalam Indonesia, 7 (1): 45 - 67. pISSN. 2406 8969; eISSN. 25490621.

Larasati AL, Haribowo C. 2020. Penggunaan Desinfektan dan Antiseptik Pada Pencegahan Penularan Covid-19 di Masyarakat. Majalah Farmasetika. Vol 5 no 3. DOI:

https://doi.org/10.24198/mfarmasetika.v $5 \mathrm{i} 3.27066$.

Ayumi IdE., Lutfi, MW, A. Nugroho. 2017. Efektivitas Tipe Pengomposan (Konvensional, Aerasi, dan Rak Segitiga) terhadap sifat fisik dan kimia kompos dari sludge biogas dan Serbuk Gergaji. Jurnal Keteknikan Pertanian Tropis dan Biosistem Vol.5 No.3, 265272.

Bachtiar B. dan Ahmad AH. 2019. Analisis Kandungan Hara Kompos Johar Cassiasiamea Dengan Penambahan Aktivator Promi. Jurnal Biologi Makassar, 4(1) : 68-76.

Gesriantuti N, Elsie, I. Harahap, N. Herlina, Y. Badrun. 2017. Pemanfaatan Limbah Organik Rumah Tangga Dalam Pembuatan Pupuk Bokashi Di Kelurahan Tuah Karya, Kecamatan Tampan, Pekanbaru. Jurnal Untuk Mu negeRI VOL. 1, NO.1 : $72-77$. ISSN : 2550-0198.

Tandra H. 2020. Virus Corona Baru Covid19, Kenali, Cegah, Lindungi diri sendiri dan orang lain.

ISBN: 978-623-7239-vv-4,

Edisi/Cetakan: I, 1st Published, Penerbit : Andi.

Bender L (Education UNICEF NYHQ), dengan dukungan teknis dari anggotaanggota UNICEF COVID-19 Secretariat (Carlos Navarro Colorado, Maya Arii \& Hugo Razuri) serta tim UNICEF WASH, C4D dan Child Protection. Maida Paisic
(UNICEF EAPRO), Le Anh Lan (UNICEF Vietnam), Tserennadmid Nyamkhuu (UNICEF Mongolia), Dr, Maria D Van Kerkhove (WHO) dan Gwendolen Eamer (IFRC). 2020. Pesan dan Kegiatan Utama Pencegahan dan Pengendalian Covid-19 di Sekolah. Unicef, World Health Organization, International Federation of Red Cross and Red Crescent Societies (IFRC). Education in EmergenciesUNICEF New York.

Yunus NR, Rezki A. 2020. Kebijakan Pemberlakuan Lockdown Sebagai Antisipasi Penyebaran Corona Virus Covid-19. Jurnal Sosial \& Budaya Syar-i FSH UIN Syarif Hidayatullah Jakarta Vol. 7 No. 3 (2020), pp.227-238, DOI: 10.15408/sjsbs.v7i3.15083.

Utomo PB, Nurdiana J. 2018. Evaluasi Pembuatan Kompos Organik Dengan Menggunakan Metode Hot Composting. Jurnal Teknologi Lingkungan, Volume 2, Nomor $01,28-32$.

Ausrianti R, Andayani RP, Surya DO., Suryani U.. 2020. Edukasi Pencegahan Penularan Covid 19 serta Dukungan Kesehatan Jiwa dan Psikososial pada Pengemudi Ojek Online. Jurnal Peduli Masyarakat Vol 2. No 2. Hal $59-64$. Global Health Science Group.

p-I SSN 2715-6524. e-ISSN 27219747.

Suwatanti EPS dan Widiyaningrum P. 2017. Pemanfaatan MOL Limbah Sayur pada Proses Pembuatan Kompos. Jurnal MIPA 40(1) : 1-6. ISSN 0215-9945.

Tortora, G.J., Funke, B.R., and Case, C.L. 2016. Microbiology: an introduction. twelfth edition. Pearson education, inc., US.

Zendrato W, 2020. Gerakan Mencegah Daripada Mengobati Terhadap Pandemi Covid-19. Jurnal Education And Development, vol. 8, no. 2, p. 242. pISSN 2527 - 4295, e- ISSN 2614 6061.Penerbit : Institut Pendidikan Tapanuli Selatan. 
Yuliana. 2020. Wellness and Healthy Magazine. Volume 2, Nomor 1, February, p.187 - 192, ISSN 2655-9951 (print). ISSN 2656-0062 (online).

Zahrotunnimah. 2020. Langkah Taktis Pemerintah Daerah Dalam Pencegahan
Penyebaran Virus Corona Covid-19 di Indonesia. Jurnal Sosial \& Budaya Syari. FSH UIN Syarif Hidayatullah Jakarta Vol. 7 No. 3 (2020), pp.247-260, DOI: $10.15408 /$ sjsbs.v7i3.15103. 